\title{
TROSKA PROFESORA FRANCISZKA GRONOWSKIEGO O POLSKĄ MYŚL MORSKĄ W XXV SEJMIKACH MORSKICH
}

\author{
Krzysztof Puc \\ Organizator Sejmików Morskich
}

Profesor Franciszek Gronowski to wybitny autorytet naukowy z zakresu problematyki morskiej, rektor, dziekan, kierownik instytutu i katedr morskich, działacz w najróżniejszych agendach gospodarki morskiej, kierownik zespołów przygotowujących ekspertyzy naukowe i założenia do strategicznego rozwoju transportu morskiego. Mimo ogromu pracy dydaktycznej i naukowej, nie skąpił pomocnej dłoni i swego dorobku naukowego, gdy w grę wchodziły sprawy polskiego morza. I tak się też stało w 1985 roku, kiedy w środowisku PAX w Szczecinie zrodziła się społeczna inicjatywa powołania Rady Morskiej PAX-u, której głównym zadaniem było podjęcie szeroko zakrojonych działań przywracających właściwą rangę sprawom polskiego morza.

Ta inicjatywa została wcześniej poprzedzona wieloma próbami organizowania interdyscyplinarnych dyskusji w stowarzyszeniu, które by gromadziły wokół problematyki morskiej ludzi kompetentnych, zaangażowanych, oddanych sprawom polskiego morza.

Sprawując funkcję kierownika referatu społeczno-ekonomicznego, przejętego po Jerzym Golińskim, organizowałem wiele różnorodnych dyskusji, konferencji, spotkań. Zapraszałem szczególnie z gdańskiego środowiska naukowego takie autorytety naukowe jak: prof. A. Piskozuba, prof. J. Zaleskiego, doc. Rzepeckiego, prof. W. Andruszkiewicza, prof. Z. Sójkę i innych, po to, by ożywić środowisko intelektualne Szczecina, zasiać pozytywny ferment i twórcze myślenie o sprawach morza. Chcę powiedzieć, że te spotkania nie wpłynęły automatycznie na zmianę usytuowania spaw morza w naszym życiu politycznym czy gospodarczym w tamtym czasie, ale doskonale opisywały morską rzeczywistość. Powoli wokół rady Morskiej PAX-u, pojawiali się ludzie nauki i praktyki gospodarczej i stawali się sojusznikami walki o morskie sprawy. Trzeba było jednak szukać bardziej skutecznych form i metod społecznego oddziaływania. Po dyskusji powstała inicjatywa powołania instytucji Sejmików Morskich, jako platformy, w ramach której będą realizowane cele Rady Morskiej PAX-u.

Profesor Franciszek Gronowski był u samych narodzin tej inicjatywy, a w jaki sposób znalazł się gronie twórców tej inicjatywy, znalazłem odpowiedź w książce Wysychające morze P. Zielińskiego, w której Profesor wspomina:

Nie ma morskiego państwa bez polityki morskiej - a bez świadomości morskiej nie ma morskiego narodu. Jeśli znajdą się uczciwi ludzie i wykazują doskonałą determinację, to mogą dużo osiągnąć, nawet w trudnych warunkach. Takim człowiekiem był właśnie Jerzy Goliński. Widział, jak 
bardzo maleje świadomość morska Polaków, dostrzegał, że nasze państwo nie prowadzi żadnej polityki morskiej. Chciał jakoś temu zaradzić. Poznałem go właśnie w związku z sejmikami. Zadzwonił do mnie i zaproponował, abyśmy wspólnie usiedli nad tym tematem. (...) Było to przed pierwszym sejmikiem w Słupsku. Nie znaliśmy się wcześniej. (...) Z naszej rozmowy dość długiej, wyszło w końcu, że trzeba zorganizować morską imprezę sesję, konferencję. (...) Ale nie może być to jednorazowy występ, ponieważ impreza nawet najlepsza, szybko się rozpłynie w nijakość na tle innych wydarzeń. Tak jak jeden zastrzyk nie wyleczy poważnej choroby, tak i w tym przypadku istnieje konieczność powtórzeń. Przyświecała nam idea, ażeby nie dopuścić do dalszego gaśnięcia świadomości morskiej, chodziło o to, aby nie słabła. Nie mieliśmy złudzeń, że zrobimy rewolucję.

Od tego momentu na trwałe zaczęła się długoletnia przygoda Profesora Gronowskiego z Semikami Morskimi. Uczestniczył w nich przez prawie ćwierć wieku (nie brał udziału jedynie w sejmiku zorganizowanym w Słupsku w 1990 r.). Aktywność Profesora przejawiała się wielokierunkowo. Był moderatorem obrad, autorem bardzo wielu referatów problemowych, recenzentem większości sejmikowych wydawnictw, autorem tez i wniosków, pomysłodawcą wielu usprawnień w funkcjonowaniu sejmików, osobą wspierającą tę inicjatywę w środowisku naukowym, gospodarczym i wśród studentów. Warto przypomnieć, oczywiście w dużym skrócie, najważniejsze tezy, myśli i refleksje formułowane na kolejnych Sejmikach Morskich, a dotyczące współczesnej polskiej myśli morskiej.

Profesor uczestniczył w pierwszym sejmiku w Słupsku w 1985 roku. Jego tematem był „Stan i perspektywy spraw morskich w Polsce”. Główne referaty przygotowali naukowcy ze wschodniej części wybrzeża. W burzliwej dyskusji dominowali jednak przedstawiciele Pomorza Zachodniego. I Sejmik Morski okazał się w sumie sukcesem organizacyjnym, a jego uczestnicy poczuli się powołani do dalszych działań - ziarno zostało zasiane.

Na II sejmiku (Szczecin 1986 r.), którego hasłem było „Port - miasto - region - kraj”, Profesor wskazywał, że:

...gospodarka morska nie jest gospodarką jednego kraju. Gospodarka morska w tym gospodarka morska Polski, coraz bardziej uzależniona jest od sytuacji światowej i to w zakresie żeglugi, portów, rybołówstwa morskiego i innych dziedzin. A więc problem międzynarodowego podziału pracy, określonych branż gospodarki morskiej, miejsce jakie kraj w nim zajmuje, co sobą reprezentuje, jakie ma szanse zmiany w międzynarodowym podziale pracy - wszystko to przesądza o jego przyszłym miejscu w społeczności światowej, w tym morskiej. A więc problem ten nie jest tylko problemem krajowym, uzależnionym od czynników wewnętrznych, lecz w poważnym stopniu zależy od czynników zewnętrznych...

Na III sejmiku (Gdańsk 1987 r.) poświęconym zharmonizowaniu ogniw składowych polskiej gospodarki morskiej, Profesor przedstawił obszerny referat poświęcony funkcjonowaniu i rozwojowi polskiej żeglugi morskiej w drugiej połowie lat 80. XX wieku. Ocenił sytuację w żegludze polskiej i wskazał na zjawiska, które nadal są aktualne, a mianowicie na problem odnowienia i restrukturyzacji tonażu. Zwrócił uwagę na szczególnie trudny okres dla żeglugi liniowej oraz na żeglugę promową jako nadzieję sukcesu.

IV sejmik (Koszalin-Kołobrzeg) był dwutematyczny. Pierwszą część poświęcono głównie ekologii morza i wybrzeża morskiego, drugą - gospodarce morskiej w warunkach reformy go- 
spodarczej. Sprawy żeglugi morskiej prezentowane były fragmentarycznie, głównie w zakresie potrzeb zmiany struktury floty handlowej i dostosowania jej do nowych wymagań obsługi ładunków. Mówiono o bolączkach zamierzeń modernizacyjno-restrukturyzacyjnych polskiej floty. Wskazywano na brak środków inwestycyjnych.

Głównym tematem V sejmiku (Elbląg 1989 r.) była ocena polityki morskiej państwa. W dyskusji nie zostawiono „suchej nitki” na prezentowanym przez resort stanowiskiem. Sejmik miał również charakter małego jubileuszu. Prof. Z. Sójka dokonał oceny pięcioletniego wkładu sejmików w rozwój polskiej myśli morskiej. Pojawił się również postulat, aby Rada Morska podjęła się organizowania innych pogłębionych spotkań w sprawach morskich.

VI sejmik (Słupsk-Ustka 1990 r.) poświęcony był przede wszystkim sprawom turystyki morskiej. Na sejmiku przyjęto stanowisko Rady Morskiej PAX w sprawie rozwoju turystyki morskiej i wykorzystania klimatyczno-przyrodniczych walorów wybrzeża.

Tematem wiodącym VII sejmiku (Szczecin 1991 r.) były „Przemiany gospodarcze i społeczno-polityczne współczesnego świata, jako wyzwanie i szansa dla polskiej gospodarki morskiej”. Profesor Franciszek Gronowski przedstawił referat, w którym mówił o przeobrażeniach systemowych światowego transportu morskiego, podstawowych uwarunkowaniach działalności polskich armatorów oraz polityce morskiej państwa jako nadziei na przyszłość. Podkreślił w nim, że: „to polityka morska powinna być przekładnią ogólnej polityki gospodarczej kraju do gospodarki morskiej i odwrotnie - polityka morska winna twórczo zapładniać politykę gospodarczą państwa”. Profesor postulował, aby podjąć możliwe i szybkie kroki, aby powstały przynajmniej podstawowe zręby polskiej polityki morskiej. Pokłosiem tego sejmiku stał się powszechny pogląd o konieczności istnienia i stosowania polityki morskiej państwa jako dokumentu rządowego. Ten dokument planistyczno-decyzyjny miałby podnieść rangę gospodarki morskiej.

VIII sejmik (Gdańsk 1992 r.). Podczas tego sejmiku, przebiegającego pod hasłem „Polska a Europa Bałtycka,, Profesor Gronowski w dyskusji wskazywał, że:

sytuacja w jakiej znajduje się nasz kraj, skutki tzw. transformacji systemowej, generalnie rzecz biorąc, nie sprzyjają wzrostowi klimatu społecznego zainteresowania i aktywności w sferze spraw morskich. W tej sytuacji z konieczności, punkt ciężkości coraz bardziej przesuwa się na tzw. inicjatywy oddolne, szeroko rozumianego lobbingu na rzecz morskości kraju. (...) Przy braku w dalszym ciągu centralnej polityki morskiej, społeczeństwo coraz bardziej oddala się od morza.

Po raz pierwszy na sejmiku poruszono problematykę Związku Miast Bałtyckich. Zaprezentowano szerokie spektrum spraw morskich, a samorząd terytorialny włączył się aktywnie w problematykę morską.

Tematyką przewodnią IX sejmiku (Mielno 1993 r.) były „Przekształcenia własnościowe i strukturalne w gospodarce morskiej”. Transformacja systemowa wywołała poważne problemy, zwłaszcza związane z projektem ustawy o portach. Na tym sejmiku Profesor Gronowski wygłosił ważny referat poświęcony przemianom organizacyjno-własnościowym w Polskiej Żegludze Morskiej. Starał się też odpowiedzieć na liczne pytania dotyczące przyszłości PŻM.

X sejmik (Krynica Morska-Elbląg 1994 r.) to sejmik jubileuszowy, którego częścią roboczą był temat „Państwo i samorządy terytorialne w polityce morskiej”. Gorąca dyskusja dostarczyła wiele wniosków, które adresowano do władz centralnych i lokalnych. Profesor Gronowski na 
tym sejmiku dokonał retrospektywnego spojrzenia na wkład poprzednich sejmików do współczesnej myśli morskiej. Ukazał jaką rolę odgrywają Sejmiki Morskie w upowszechnianiu spraw morskich wśród społeczeństwa polskiego, w kształtowaniu swego rodzaju świadomości morskiej Polaków. Stwierdził, że:

Sejmiki Morskie stanowią ożywcze źródło, które już na trwale wpisało się w pejzaż morski. Nie pozwalają, by ważkie sprawy morskie były lekceważone, by urzędy i ludzie, którzy winni się nimi zajmować - zapominali o nich.

W odrębnym komunikacie poświęconym roli państwa i samorządów terytorialnych w polityce morskiej Profesor podniósł ważny problem - czy państwo morskie może sobie pozwolić na pełny liberalizm, rezygnując z protekcjonalizmu. Profesor sformułował następującą tezę: „Tyle wolnego rynku, ile można - tyle interwencjonizmu państwa, ile konieczne” - co można w całości odnieść do polskiej gospodarki morskiej. Wszystkie branże gospodarki morskiej przeżywają regres, niektóre stoją na skraju przepaści (np. rybołówstwo morskie). Bez szybkich działań interwencyjnych, wynikających ze świadomości polityki morskiej państwa trudno oczekiwać radykalnych zmian na lepsze.

Na XI sejmiku (Słupsk 1995 r.) Profesor Franciszek Gronowski przedstawił referat „,50 lat żeglugi morskiej na Pomorzu Zachodnim”. Konkluzją tego referatu było stwierdzenie:

...bardzo trudno jest kreślić wizję przyszłości dla żeglugi morskiej Pomorza Zachodniego w następnych latach. Jedno wszakże można powiedzieć z całą pewnością, że bez kreatywnej roli państwa, rozumiejącej i doceniającej rolę żeglugi morskiej w gospodarce narodowej, nie może być mowy o generalnej zmianie. Wyrazem tego powinno być opracowanie i konsekwentna realizacja polityki morskiej Polski, długofalowego programu, celów, metod i narzędzi tej polityki. Póki co, nie ma takiej zmiany i nic nie zapowiada na lepsze.

W programie dwudniowych obrad XII sejmiku (Łukęcin 1996 r.) wyodrębniono dzień ogólnopolski i dzień regionalny. Dzień ogólnopolski poświęcono problematyce międzynarodowych uwarunkowań rozwoju transportu morsko-lądowego w Polsce. Obrady podzielono na cztery grupy tematyczne. Pierwsza z nich dotyczyła dostosowania polskiego systemu transportowego do wymogów międzynarodowych w świetle postanowień Układu Europejskiego o Stowarzyszeniu Polski z Unią Europejską. Druga grupa tematyczna dotyczyła transportu morskiego, trzecia - portów morskich, a czwarta - transportu lądowemu w kontekście obsługi gospodarki morskiej. Cała dyskusja przebiegała w duchu szans i zagrożeń płynących dla polskiego systemu transportowego z postanowień Układu Europejskiego o Stowarzyszeniu Polski z Unią Europejską. W drugim dniu obrad samorządy terytorialne województwa szczecińskiego przedstawiły swoje działania i dokonania na rzecz rozwoju gospodarki regionu. Prezentacja skutecznej pracy samorządów terytorialnych w rozwiązywaniu lokalnych problemów morskich i wykorzystywaniu nadmorskiego położenia gmin, to również jedna $\mathrm{z}$ wielu propozycji koncepcyjnych Profesora Gronowskiego.

Przewodnim tematem XIII sejmiku (Gdańsk 1997 r.) była „Polska myśl bałtycka”. Sejmik obradował w czasie i w ramach obchodów tysiąclecia Gdańska. Przypomniano na nim słowa prof. Jerzego Zaleskiego: „Bałtyk jest morzem polskiego przeznaczenia. (...) Ilekroć Polska traciła z pola widzenia swe interesy morskie i malał jej wpływ na bieg spraw na Bałtyku, tylekroć 
odbijało się to na spadku jej roli i pozycji politycznej w Europie”. Nowym elementem w obradach sejmikowych była problematyka współpracy regionalnej województw nadmorskich z państwami bałtyckimi. W dyskusji Profesor Gronowski zwrócił uwagę, na konieczność rozwijania żeglugi promowej jako podstawowego ogniwa VI europejskiego korytarza transportowego północ-południe prowadzącego przez porty Gdańsk-Gdynia i autostradą A1. Jak podkreślił: „jeśli tego w najbliższym czasie nie zrobimy, to stracimy wiele korzyści płynących z żeglugi promowo-towarowej, która powinna przekształcić się później w pasażersko-towarową, a nawet kolejową". Profesor zgłosił również postulat, aby jeden z sejmików poświęcić ocenie transformacji systemowej w gospodarce morskiej, do jakiej doszło w pierwszym dziesięcioleciu i na tym tle zaproponować - co dalej?

XIV sejmik (Szczecin 1998 r.) poświęcony był w całości „Edukacji morskiej w Polsce”. Była to realizacja wielu postulatów i głosów w dyskusji, podkreślających, że edukacja morska w Polsce jest wciąż postulatem, a świadomość morska Polaków i wiedza o morzu w naszym kraju jest żenująco niska. Główna konkluzja sejmiku brzmiała: „należy pobudzić ośrodki państwowe, ośrodki społeczne, mass media do stałego zwiększania udziału w promowaniu morza w gospodarce narodowej i świadomości społecznej”. Była to między innymi realizacja postulatu Profesora Franciszka Gronowskiego, który tak często na sejmikach przywoływał oczywistą prawdę, że „bez polityki morskiej nie ma państwa morskiego. Bez świadomości morskiej - nie ma narodu morskiego". Siłę Polski na morzu trzeba mierzyć siłą polskiej gospodarki i siłą społecznego poparcia dla polskich spraw morskich. W równym stopniu należy dbać o rozwój gospodarki morskiej Polski, jak i krzewienie i pogłębianie świadomości polskiego społeczeństwa. Bez tych elementów trudno będzie można mówić o efektywnej i racjonalnej „uprawie morza”.

Tematem głównym XV sejmiku (Kamień Pomorski 1999 r.) były „Małe porty morskie oraz ich otoczenie lokalne i regionalne”. Profesor Gronowski był sekretarzem naukowym i recenzentem przygotowanych materiałów. Głównym założeniem sejmiku, było dostarczenie samorządom lokalnym, pragmatycznych wskazań, jak najlepiej wykorzystać ich potencjał rozwojowy. Sejmik z racji swojego jubileuszowego charakteru zawierał również sporo elementów przypominających te wnioski, które rodziły się na sejmikach a podkreślały morską rację stanu Polski. Profesor wskazał, że „refleksja ogólna jubileuszu 15 lat sejmikowania nie jest jednak budująca” i wyraził nadzieję, że „muszą przyjść lepsze lata i wiele z wniosków podejmowanych na Sejmikach Morskich doczeka się wreszcie realizacji”. W podsumowaniu Profesor stwierdził, że „małe porty i przystanie morskie są dużą szansą dla rozwoju miast i gmin morskich, a także dla gospodarki narodowej. Ich rozwój leży zarówno w interesie władz samorządowych, jak i państwa”.

XVI sejmik (Kołobrzeg-Grzybowo 2000 r.) z założenia miał być poświęcony „żegludze i portom morskim w perspektywie integracji Polski z Unią Europejską". W trakcie obrad tematyka ta została znacznie poszerzona o wiele zagadnień natury ogólnej. Temat „Polska u progu Unii Europejskiej” dominował w bardzo interesującej dyskusji. Konkretyzację problemową do obrad wnieśli przedstawiciele żeglugi i portów morskich polskiego wybrzeża. Profesor Gronowski dokonaj oceny 15 dotychczasowych Sejmików Morskich oraz przedstawił swoje uwagi i sugestie odnośnie do przyszłych sejmików. W swojej ocenie zauważył, że „Największe znaczenie morskiego sejmikowania widzę w tym, że kultywuje myśl morską oraz utrwala w społeczeństwie tzw. świadomość morską". Sentencja płynąca z XVI Sejmiku w Grzybowie to stwierdzenie Profesora zawarte w nocie recenzenta: 
w czasie kiedy Polska usilnie zmierza do członkostwa w Unii Europejskiej, konieczne jest uwypuklenie spraw morza, nie tylko portów i żeglugi. (...) Jest to temat ciągły, nawet kiedy już wejdziemy do Unii Europejskiej. Ma on nie tylko wartość poznawczą, ale i pragmatyczną ,np. dostosowanie naszego ustawodawstwa do legislacji morskiej Unii.

XVII sejmik (Gdańsk-Hel 2001 r.), był sejmikiem jednotematycznym, poświęconym „Turystyce morskiej" i dotyczył spraw regionalnych.

XVIII sejmik (Gdańsk-Jastarnia 2002 r.) poświęcono społeczno-gospodarczym skutkom przemian własnościowych i organizacyjnych w gospodarce morskiej. Profesor Gronowski wygłosił referat „Polityka morska państwa”. Motto jakie towarzyszyło referatowi to słowa: „Bez polityki morskiej państwa nie ma państwa morskiego. Bez świadomości morskiej - nie ma narodu morskiego". To hasło Profesora pojawiało się na sejmikach bardzo często, gdyż ma swoje głębokie uzasadnienie. Profesor podkreślił, że ciągły brak polityki morskiej państwa to nic innego jak „grzech zaniechania”, polegający na pozostawieniu gospodarki morskiej samej sobie. Szybko zbliżający się termin pełnego członkostwa Polski w Unii Europejskiej, postawił pod znakiem zapytania kwestię szans i zagrożeń z tym związanych w naszej gospodarce morskiej. Szczególną uwagę zwracano na niezmiernie trudną sytuację w jakiej znalazła się polska żegluga morska, jej stale postępującą degradację. Pewnym przebłyskiem, czy przebudzeniem władz centralnych, był przedstawiony na sejmiku przez Ministra Infrastruktury „Raport o stanie gospodarki morskiej wraz z elementami strategii do 2004 roku”. Został on jednak odebrany przez uczestników sejmiku jako zbyt ogólny i jedynie hasłowy, czemu dano wyraz w dyskusji.

Na XIX sejmiku (Gdańsk-Kopenhaga 2003 r.) kontynuowano problematykę, która już kilkakrotnie była podnoszona, a dotyczyła polskiej myśli bałtyckiej i nawiązywała do postulatu uczynienia z basenu Morza Bałtyckiego jednego z podstawowych regionów integracji europejskiej. Obrady odbywały się w dwóch ośrodkach po obu stronach Bałtyku - w Gdańsku i Kopenhadze. Ze względu na rolę gospodarki morskiej w tworzeniu coraz ściślejszej sieci współzależności w Europie Bałtyckiej, znaczną część referatów poświęcono rozwojowi żeglugi i portów oraz współpracy morskiej w kontekście poszerzenia Unii Europejskiej. Ważne miejsce w obradach zajęła problematyka współpracy w żegludze bliskiego zasięgu państw nadbałtyckich. Profesor Gronowski był recenzentem sejmiku, przewodniczącym obrad i autorem skrótowej oceny 18 Sejmików Morskich.

XX jubileuszowy sejmik (Darłowo-Kopenhaga 2004 r.), poza tematem wiodącym „U progu Unii Europejskiej - Bałtyk morzem bezpiecznym” skłonił organizatorów do kolejnego retrospektywnego spojrzenia na wkład 19 sejmików w kształtowanie współczesnej myśli morskiej. Profesor Gronowski z bogactwa tematów 19 sejmików, dokonał wyboru zagadnień dotyczących problematyki żeglugi i transportu. W ramach głównego tematu wygłosił referat „Zmiany tonażowe polskiej floty handlowej na przestrzeni lat 1985-2002”. Ukazał w nim jaki był stan i jakie zmiany zachodziły w polskiej flocie handlowej przez ostatnie 17 lat. Profesor podją również próbę syntetycznej oceny dorobku Sejmików Morskich, wskazując na bardzo wiele pozytywów, ale i smutnych refleksji:

Dwadzieścia corocznych spotkań (Słupsk 1985 - Darłowo 2004), unikalne zjawisko w naszej powojennej rzeczywistości. Nie znam drugiej takiej inicjatywy która by tak konsekwentnie i z uporem, pomimo rozlicznych trudności, kultywowała tematykę polskiej gospodarki morskiej. (...) 
Tak olbrzymi wkład intelektualno-merytoryczny nie przekładał się niestety na zmianę negatywnych zjawisk w naszej gospodarce morskiej. (...) Poza „sumieniem społecznym jakimi są sejmiki nie miały one uprawnień egzekwowania swoich słusznych postulatów.

XXI sejmik (Elbląg-Kaliningrad 2006 r.) poza wymianą poglądów na temat współpracy w Euroregionie, ukazał koncepcję klasterów, jako organizacji wpływających na rozwój regionu. Ponownie wróciła problematyka małych portów morskich, a w szczególności tematyka morskiego portu w Elblągu, ukazująca dotychczasowe funkcjonowanie tego portu jak i jego problemy rozwojowe.

Główny temat XXII sejmiku (Świnoujście-Ystad 2006 r.) to „Dwa lata polski morskiej w Unii Europejskiej”. Koncepcja tego sejmiku zrodziła się w dyskusji z naukowcami Wydziału Zarządzania i Ekonomiki Usług US. Zasugerowano, aby nawiązać do tych sejmików, które podejmowały problematykę wejścia Polski do Unii Europejskiej, szczególnie do sejmiku w Grzybowie, gdzie opracowano ponad 40 wniosków, kierując je do rządu i parlamentu. Wspomnę tylko jeden z nich, którego współautorem był Profesor Gronowski.

Państwo polskie w okresie przedakcesyjnym powinno dołożyć wszelkich działań, aby prace dostosowawcze do wymogów i standardów Unii Europejskiej odnosiły się nie tylko do sfery legislacyjnej, ale także do tworzenia warunków finansowo-ekonomicznych i infrastruktury polskich podmiotów transportu morskiego (żeglugi i portów) zbliżonych poziomem do warunków w jakich pracują podmioty państw członkowskich Unii.

W wyniku bardzo rzeczowej dyskusji, która przebiegała w trzech blokach tematycznych: polityka morska, transport morski, pozostałe struktury morza - żegluga śródlądowa, udało się sformułować wnioski i postulaty jakie Polska powinna wprowadzić do Złotej Księgi. W drugiej części obrad znów sięgnięto do pięknej tradycji, do sejmikowaniu o problemach lokalnych. Organizatorzy sejmików zwrócili się do grona naukowców, polityków i praktyków gospodarczych, którzy sprawami uprawy morza są głęboko zainteresowani, by odbyć debatę na temat „Polska myśl morska XXI wieku”. To hasło stało się głównym tematem XXIII sejmiku (Kołobrzeg 2007 r.). W interesujący sposób zaproponowano odbycie dyskusji w panelach problemowych. Pierwszy panel - główne kierunki myśli morskiej - tradycja i współczesność; drugi panel - polityka morska - wybrane zagadnienia; trzeci panel - współczesna praktyka morska - wybrane zagadnienia; czwarty panel - regiony nadmorskie w warunkach nowej gospodarki - innowacyjność i konkurencyjność. Organizatorem tego sejmiku oprócz Civitas Christiana był Wydział Zarządzania i Ekonomiki Usług US, a Profesor Franciszek Gronowski został recenzentem tomiku. Sentencja płynąca z tego sejmiku była następująca:

Działania związane z kształtowaniem polskiej gospodarki morskiej miały swój intelektualny fundament, czyli myśl, na którą składały się takie zjawiska jak: refleksja, analiza empiryczna oraz oparte na naukowych zasadach wnioskowanie, budowanie teorii, doktryn, koncepcji, programów, strategii. Współczesne przemiany kulturowo-cywilizacyjne, których przejawami są takie procesy jak: globalizacja, ponadnarodowa integracja, a w przypadku Polski - transformacja systemowa, spowodowały, że znaczenie morza, jako mostu między kulturami i cywilizacjami, uległo nie tylko osłabieniu, ile zapomnieniu. 
Na przykład o ile w latach 90. nowo powstałe samorządy terytorialne dostrzegały szanse wynikające z nadmorskiego położenia, to z czasem zapał w tym zakresie osłabł lub się wypalił. Dlaczego tak się dzieje? Organizatorzy sejmiku postawili tezę, że jest to konsekwencją stopniowego zanikania oryginalnej, odpowiadającej współczesnym uwarunkowaniom cywilizacyjnym myśli morskiej. I poszli dalej w stawianiu pytań. Czy polska myśl morska w XXI wieku jest w ogóle potrzebna? A jeśli tak, to w jakim zakresie, kształcie i jakie merytoryczne obszary powinna obejmować. Pomocą w odpowiedzi był przygotowany przez organizatorów do dyskusji panelowej arkusz 10 kwestii, w tym pytania o ocenę dotychczasowej i aktualnej polityki morskiej Polski.

XXIV sejmik (Gdynia 2008 r.), był sejmikiem wielotematycznym, niełączącym się w jakąś logiczną całość. Tematami były: 90 rocznica powstania floty polskiej, współczesne fundusze Unii Europejskiej dla gospodarki morskiej, rozwój VI korytarza transportowego oraz wspólna przestrzeń portu i miasta na przykładzie Gdyni. Dokonano również przedstawienia osiągnięć dwudziestolecia międzywojennego w rozwoju Marynarki Wojennej.

Tematem przewodnim pierwszego dnia jubileuszowego XXV Sejmiku Morskiego (Szczecin 2010 r.), który odbywał się w trakcie Centralnych Dni Morza, była dyskusja nad koncepcją Europy Bałtyckiej w jej globalnym otoczeniu, w tym nad dokumentem „Strategia UE w regionie Morza Bałtyckiego". W drugim dniu obrad skoncentrowano się nad problematyką regionalną - osi transportowej łączącej region bałtycki ze środkową i południową Europą (CETC) i kwestią bezpieczeństwa energetycznego Polski w aspekcie realizacji koncepcji terminalu LNG w Świnoujściu. Referat otwarcia pierwszego dnia sejmiku - „Sejmiki Morskie, geneza, cele, rzeczywistość”, zaprezentował Profesor Gronowski. W syntetycznej analizie dokonał identyfikacji okoliczności powstania sejmików przywołując pamięć Jerzego Golińskiego - twórcy koncepcji Ośrodka Myśli Morskiej, przypominając jego zasługi i dokonania. Podkreślił również, że Sejmiki Morskie w mijającym ćwierćwieczu stworzyły specyficzny klimat dla uprawy morza, pewną przestrzeń dla artykulacji najważniejszych problemów polskiego morza. W ocenie Profesora:

sejmiki spełniły swoją rolę tak w okresie transformacji, w przededniu akcesji Polski do Unii Europejskiej, jak i w pierwszych latach naszego członkostwa w strukturach europejskich. Sejmiki były zawsze miejscem głośnego wołania o program, o strategię i politykę morską państwa, były gwarantem interdyscyplinarnego spojrzenia na sprawy morza i niczym nieskrępowanej dyskusji. Spełniały też ważną funkcję kreacyjną, formułując pod adresem twórców polityki morskiej określone propozycje programowe. Jedną z myśli przewodnich sejmików była próba aktywizacji organów samorządowych do stworzenia zrębów regionalnej polityki morskiej. To, że Sejmiki Morskie zyskały tak wysoką rangę, to przede wszystkim zasługa rzeszy naukowców, praktyków gospodarki morskiej, instytucji i organizacji morskich, którzy mają na swym koncie liczne sukcesy w postaci twórczego rozwoju polskiej myśli morskiej.

Ten wkład był tak poważny, że już po pięciu sejmikach, które przecież odbywały się w innej rzeczywistości społeczno-politycznej, dorobek myślowy i programowy tamtych spotkań pozwolił na sformułowanie w 1989 roku „Oświadczenia Rady Morskiej Stowarzyszenia PAX” w sprawie polityki morskiej państwa. W oświadczeniu tym wskazano na znaczenie dostępu Polski do morza dla jej narodowego i państwowego bytu. Wychodząc z tych racji apelowano o zwrócenie się całą siłą woli narodu w stronę morza. Postulowano opracowanie i realizację 
w całościowym ujęciu, programu dalekosiężnej polityki morskiej państwa. Był to wówczas jedyny głos w ogólnonarodowej dyskusji jaka się toczyła na temat przebudowy naszej gospodarki morskiej.

Ten krótki chronologiczny przegląd tematyki 25 sejmików i merytorycznego udziału w nich Franciszka Gronowskiego pokazał jak duży wkład w to dzieło miał Profesor. Jednocześnie materiał ten można potraktować jako rozszerzenie rozważań na ten temat przedstawionych w publikacji związanej z jubileuszem 75-lecia urodzin Profesora F. Gronowskiego przez profesorów S. Szwankowskiego oraz Z. Sójkę.

Myśl morska Profesora Gronowskiego stała się trwałym dorobkiem Sejmików Morskich. Jego zawsze aktualne i trafne oceny, spostrzeżenia, uwagi dotyczące praktycznie wszystkich najważniejszych spraw morskich Polski zapisały się jako ogromny wkład w kształtowanie myśli morskiej. Profesor jest autentycznym autorem sejmikowych sukcesów i dlatego z dumą może mówić „nasze sejmiki”.

Dziękując za wspaniałą współpracę, życzę szacownemu Jubilatowi, aby doczekał się spełnienia swoich marzeń „Żeby Polska była Morską”. 